\title{
Management strategy for innovation and investment activities of an enterprise
}

\author{
Nikolay Voytolovskiy ${ }^{1, *}$, Vera Pogodina ${ }^{1}$, and Maria Ivanova $^{2}$ \\ ${ }^{1}$ Saint Petersburg State Economic University, 21, Sadovaya Street, 191023, St. Petersburg, Russia \\ ${ }^{2}$ St. Petersburg state University of civil aviation, 38, Pilotov str., 196210, St. Petersburg, Russia
}

\begin{abstract}
The purpose of this paper is to develop a strategy for managing the innovation and investment activity of an industrial enterprise at various stages of its life cycle. Based on the analysis and assessment of the efficiency of the implementation of existing strategies, the relevant features of innovation and investment activities of enterprises have been identified. A methodological approach to assessing the meso- and macroeconomic effect of the implementation of transformations at the enterprise depending on the stage of the life cycle is proposed, and an algorithm for determining the most optimal development strategy, which is based on an analysis of the parameters of predicted stability, is compiled. As a result of the study, a new approach to the formation of innovative and investment development of an enterprise was formed, which allows taking into account not only the change in the internal indicators of the economic activity of an enterprise, but also the change in external parameters. In addition, the proposed approach allows determining the economic effect on the basis of a combined assessment of the dynamics of introducing product, technological and managerial innovations, taking into account the efficiency of attracting investment resources that ensure the implementation of innovative transformations.
\end{abstract}

\section{Introduction}

The modern innovation activity of industrial enterprises comes down to adaptation to the current market situation through the introduction of low-efficiency point innovations and is characterized by the absence of an enterprise innovation strategy that would allow the creation and implementation of large-scale innovations, different in type and form, capable of generating high added value.

In order to innovatively update the economy, it is necessary to carry out a set of systemic innovative transformations at industrial enterprises at various stages of the life cycle, based on the development and implementation of a strategy for managing their innovation and investment activities. Moreover, these transformations in industrial enterprises should be considered on the basis of a comprehensive analysis as an interconnected set of reproduction processes that have a certain cyclical nature. The need for a comprehensive study is caused by the influence of innovative infrastructure and

* Corresponding author: voytolovskiy@mail.ru 
investment potential of the external environment (industries, regions, countries) on the innovative development opportunities of an economic entity.

The reorientation of the economic system to innovative activity requires the attraction of both external and internal investments of various types and forms in the required volumes. It should be noted that the innovative and investment processes at the enterprise must be considered comprehensively on the basis of logically selected and economically sound indicators of the business entity with the synergetic effect taken into account [1].

The study proposed to supplement and clarify the life cycle of an innovative enterprise, since the most optimal and acceptable forms of innovative transformations and ways of their investment support were identified for each stage of the enterprise's development. Thus, continuous comprehensive innovative transformations based on the development and production of new or improved products, the introduction of new production technologies, new business processes and organizational tools based on continuous financial investment support at all stages of the business structure life cycle will prevent bankruptcy, liquidation or undesirable takeover of a business entity [2].

\section{Materials and Methods}

The analysis of approaches to the innovation and investment development of business entities at various stages of the life cycle and the refinement of the economic category of the enterprise as a complex economic system that is in need of innovative transformations allowed the author to develop a model of investment and innovation activity of an enterprise (Figure 1).

Using the proposed model by the owners and the enterprise management will allow achieving maximum values of both social and economic effects from the implementation of the innovative development strategy based on the accounting and analysis of the whole set of aspects of the enterprise's innovative and investment activity, while the developed approach allows new factors to appear within the above groups. It should be noted that these aspects should act with a certain systematic nature and be characterized by interconnectedness and complexity, taking into account the effect of mutual influence [3].

One of the features of the proposed model is the gradation of the results of activities of an economic entity on an economic and social basis. It should be noted that an increase in fiscal efficiency and an increase in the profit of business entities lead to an increase in the real growth of household incomes (pensions, benefits, wages, etc.), which leads to a positive change in the social effect based on the synergetic effect [4].

Further study of the problems of assessing and analyzing innovation and investment transformations led to the conclusion that the effectiveness of these transformations at the macro and mesoscale levels will be directly dependent on the achieved economic and social effects.

$$
\mathrm{Ef}_{\text {invest }}^{\text {innov }}=\mathrm{Ef}_{\text {econ }}+\mathrm{Ef}_{\text {soc }}
$$

where $\mathrm{Ef}_{\text {invest }}^{\text {innov }}$ - the efficiency of innovation and investment transformations depending on the level of analysis (macro- or mesoscale);

$\mathrm{Ef}_{\text {econ }}$ - achieved economic effect from innovative transformations;

$\mathrm{Ef}_{\mathrm{soc}}-$ achieved social effect of innovative transformations.

In turn, the social and economic effects can be represented as the following dependencies: 


$$
\left\{\begin{array}{l}
\mathrm{Ef}_{\mathrm{econ}}=\frac{\partial \mathrm{B}}{\partial t}+\frac{\partial \mathrm{Inc}}{\partial t} \\
\mathrm{Ef}_{\mathrm{soc}}=\frac{\partial \mathrm{B}}{\partial t}+\frac{\partial \mathrm{Inc}}{\partial t}+\frac{\partial \operatorname{Prog}}{\partial t}+\frac{\partial \mathrm{E} c o l}{\partial t}
\end{array}\right.
$$

where $\frac{\partial \mathrm{B}}{\partial t}, \frac{\partial \mathrm{Inc}}{\partial t}, \frac{\partial \mathrm{Prog}}{\partial t}, \frac{\partial \mathrm{E} c o l}{\partial t}$ - change in budgetary efficiency, revenue growth of innovation and investment activity entities, acceleration of scientific and technical progress, improvement of the environmental situation, respectively.

Substituting the data of the system of equations (2) into equation (1), we obtain the following dependence:

$$
\mathrm{Ef}_{\text {invest }}^{\text {innov }}=2 \cdot\left(\frac{\partial \mathrm{B}}{\partial t}+\frac{\partial \mathrm{Inc}}{\partial t}\right)+\frac{\partial \operatorname{Prog}}{\partial t}+\frac{\partial \mathrm{E} c o l}{\partial t} .
$$

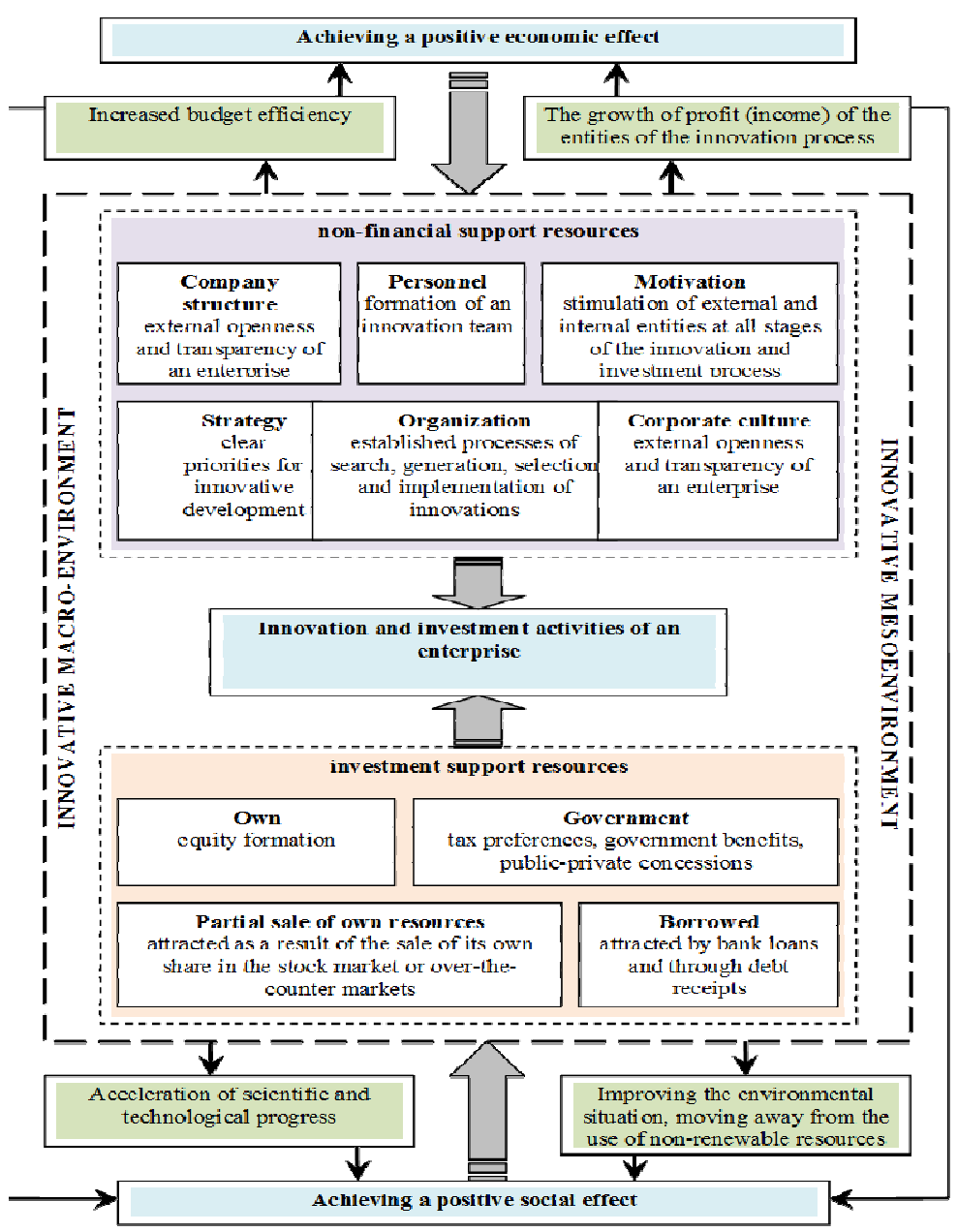

Fig. 1. Model of investment and innovation activities of an enterprise. 
Thus, in the study, as a measure of the economic effect of innovation and investment transformations at enterprises at macro- and mesoscale levels, it is proposed to understand the total value of changes in budgetary efficiency, revenues of entities of innovation and investment activity, scientific and technological progress, and the environmental situation $[5,6]$.

The innovative activity of an economic entity will involve not only the introduction of product, technological or managerial innovations, but also the preparation and development of human resources that form special behavioral models that realize the desire for innovative improvement [7].

\section{Results}

Further research of the processes of economic activity of an enterprise made it possible to separate the factors of innovative support for the systemic transformations of the economic entity according to the institutional basis and degree of activity (Figure 2).

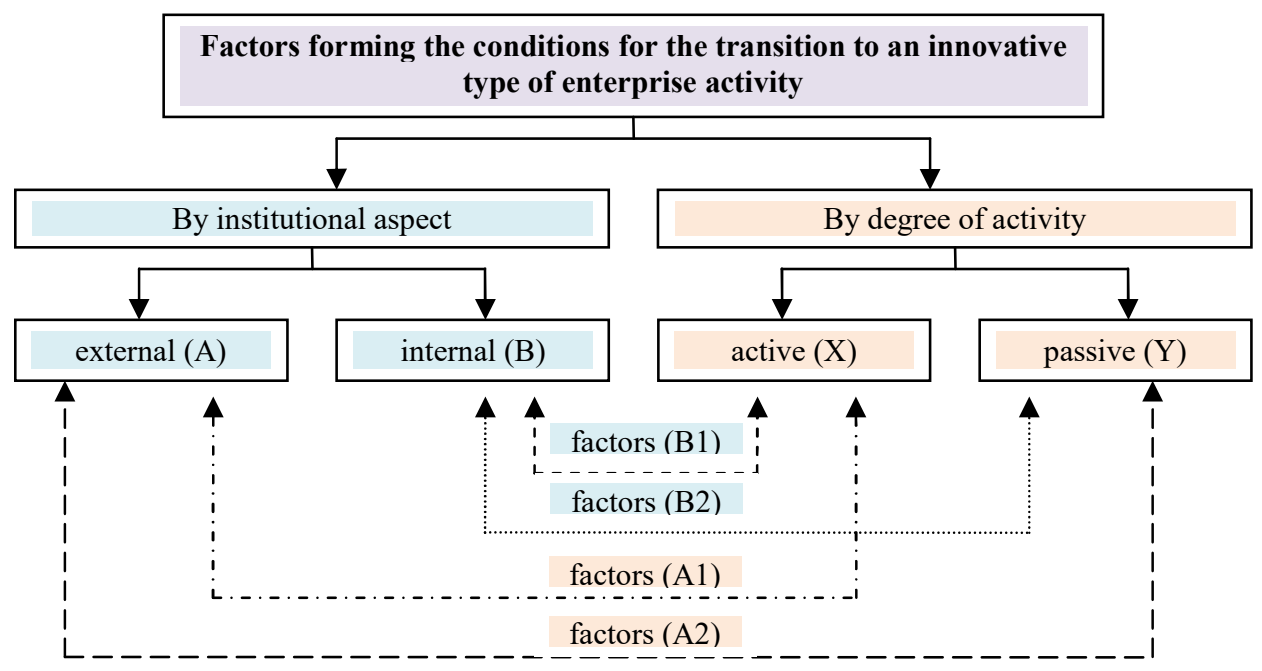

Fig. 2. Types of factors of innovative support for systemic transformations of an economic entity.

The study proposes to consider four classification types of factors that form the conditions for the transition to the innovative type of enterprise activity: external active $(\mathrm{AX})$, external passive (AY), internal active (BX), internal passive (BY). According to the author, the proposed classification covers the whole set of existing innovative incentives, and at the same time, allows taking into account the different nature of the sources of formation of innovative development factors.

Guided by the developed classification, at the next stage of the study, it is proposed to consider the probability indicator of the implementation of innovative transformations of an economic entity in the form of a matrix of factors different in classification type.

$$
\mathrm{W}_{\mathrm{INV}}=\left\{\begin{array}{cccc}
\mathrm{AX}_{1} & \mathrm{AX}_{2} & \ldots . . & \mathrm{AX}_{\mathrm{i}} \\
\mathrm{AY}_{1} & \mathrm{AY}_{2} & \ldots . . & \mathrm{AY}_{\mathrm{j}} \\
\mathrm{BX}_{1} & \mathrm{BX}_{2} & \ldots . . & \mathrm{BX}_{\mathrm{n}} \\
\mathrm{BY}_{1} & \mathrm{BY}_{2} & \ldots . & \mathrm{BY}_{\mathrm{m}}
\end{array}\right\}
$$


where $\mathrm{W}_{\mathrm{INV}}$ - the relative probability of the implementation of innovative transformations of an economic entity.

Practical application of the proposed value will allow a comparative assessment of various business entities according to their possibility (probability) and the potential for transition to an innovative type of activity. This opportunity will allow investors to reduce investment risks and make more reasonable decisions when choosing an investment object in conditions of increased demand from economic entities for attracting external financial resources.

For the convenience of practical application of the formed approach, the probability of implementing innovative transformations of an economic entity is presented in the form of the following amount:

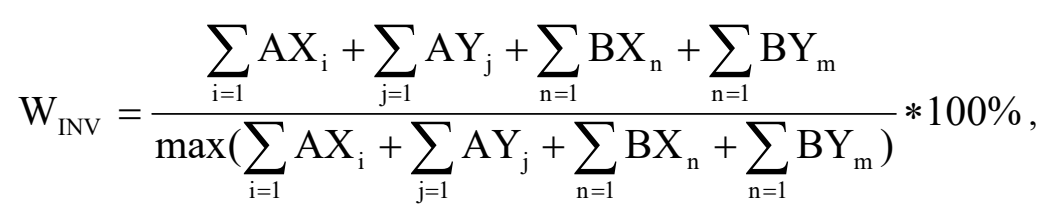

where $\sum_{\mathrm{i}=1} \mathrm{AX}_{\mathrm{i}}, \sum_{\mathrm{j}=1} \mathrm{AY}_{\mathrm{j}}, \sum_{\mathrm{n}=1} \mathrm{BX}_{\mathrm{n}}, \sum_{\mathrm{n}=1} \mathrm{BY}_{\mathrm{m}}$ - total quantitative assessment of external active, external passive, internal active, internal passive factors, respectively, that form the conditions for the transition to an innovative type of enterprise activity;

$\max \left(\sum_{\mathrm{i}=1} \mathrm{AX}_{\mathrm{i}}+\sum_{\mathrm{j}=1} \mathrm{AY}_{\mathrm{j}}+\sum_{\mathrm{n}=1} \mathrm{BX}_{\mathrm{n}}+\sum_{\mathrm{n}=1} \mathrm{BY}_{\mathrm{m}}\right)$ - maximum quantitative assessment of the above factors.

In order to ensure the universality of the proposed approach, while maintaining its complexity, which consists in a comprehensive assessment of the sources of formation of incentives for innovative activity of an economic entity, for the numerical assessment of factors having different forms of display (both qualitative and quantitative), the author suggests using the methodology of SWOT analysis with the use of a point system of the method of expert assessments.

It should be noted that the innovation market, within which an enterprise is located, can have both positive and negative effects on the innovative activities of an enterprise. Thus, a numerical assessment of a factor can have a negative range (with a negative impact on the innovative activity of an enterprise), zero value (if there is no influence), and a positive value (with a positive influence of a factor on innovative activity of an enterprise).

Given the correlation between various sources of the formation of innovative incentives, the study selected the most significant factors based on the principle of sufficiency (table $1)$.

Table 1. The list of the most significant factors forming the conditions for the transition to an innovative type of enterprise activity.

\begin{tabular}{|c|c|}
\hline Classification type & Factor \\
\hline $\begin{array}{l}\text { External active } \\
\text { factors }\end{array}$ & $\begin{array}{l}\text { 1. Direct industry or targeted subsidies or government benefits for loans } \\
\text { 2. Sectoral (regional) tax policy } \\
\text { 3. Sectoral regulatory and technical regulation }\end{array}$ \\
\hline $\begin{array}{l}\text { External passive } \\
\text { factors }\end{array}$ & $\begin{array}{l}\text { 1. The level of competition in the market } \\
\text { 2. The degree of development of education in the field of activity of } \\
\text { economic entity } \\
\text { 3. Innovative infrastructure } \\
\text { 4. Federal and regional legislative bases in the field of innovation } \\
\text { regulation }\end{array}$ \\
\hline
\end{tabular}




\begin{tabular}{|l|ll|}
\hline & 5. The degree of openness of the market to foreign capital \\
\hline Internal active & 1. & The presence of strategic and tactical levels of enterprise planning \\
factors & 2. Innovative orientation of staff. \\
& 3. Management qualifications \\
\hline Internal passive & 1. Existing production and technical base \\
factors & 2. Form of ownership and organizational structure \\
\hline
\end{tabular}

On the one hand, the proposed list is a sufficient set of factors necessary for a comprehensive assessment of the innovative potential of an enterprise, taking into account the minimization of the effect of cross-correlation, but in some cases, the proposed list can be supplemented by individual factors that also have a significant impact on the subjects of analysis of the innovative development potential of an economic entity.

The key features of the proposed approach are the ability to compare individual enterprises according to their innovative potential and determine the degree of probability of their transition to an innovative type of activity. Moreover, the study revealed the dependence of the relative value of the necessary investment resources to ensure sustainable innovative development of an economic entity on the value of the $\mathrm{W}_{\text {INV }}$ indicator (Table 2).

Table 2. Assessment of the degree of probability of the transition of an economic entity to innovation.

\begin{tabular}{|c|c|c|}
\hline $\begin{array}{c}\text { Value of the } \\
\text { indicator } \mathbf{W}_{\text {INV }}\end{array}$ & $\begin{array}{c}\text { The degree of probability of the } \\
\text { transition of an enterprise to the path of } \\
\text { innovative development }\end{array}$ & $\begin{array}{c}\text { The relative amount of } \\
\text { investment capital to ensure } \\
\text { innovative transformation }\end{array}$ \\
\hline$+100 \%<\mathrm{W}_{\mathrm{INV}}<0 \%$ & $\begin{array}{c}\text { The most favorable position in the market } \\
\text { for the purpose of further innovative } \\
\text { development }\end{array}$ & Low \\
\hline $\mathrm{W}_{\mathrm{INV}}=0 \%$ & $\begin{array}{c}\text { The absence of both prerequisites and the } \\
\text { factor of "inhibition" of } \\
\text { innovative development }\end{array}$ & Average \\
\hline $0 \%<\mathrm{W}_{\mathrm{INV}}<-100 \%$ & $\begin{array}{c}\text { The extremely negative position of an } \\
\text { enterprise on the market, the lack of } \\
\text { practical opportunities for further } \\
\text { innovative development }\end{array}$ & High \\
\hline
\end{tabular}

In the scientific works of economists, the relationships between such economic concepts as the risks of the existence/development of an enterprise, the stability of an economic entity, and the degree of its development are disclosed in detail. Based on the interconnections of the above economic categories, the paper proposes a classification of existing strategies for the development of an enterprise depending on the degree of using innovations, which made it possible to develop an algorithm for choosing a strategy for innovative and investment activity of an enterprise.

Based on the study and analysis of modern economic literature, as well as the existing practice of development of Russian enterprises that are different in terms of industry and ownership, the author identifies and characterizes the main types of strategies of economic entities, where the main classification features are the degree of development of an enterprise, its sustainability and main risks (table 3 ).

Table 3. Type of enterprise development strategies.

\begin{tabular}{|c|c|c|c|}
\hline \multirow{2}{*}{ Characteristic } & \multicolumn{3}{|c|}{ Type of enterprise development strategies } \\
\cline { 2 - 4 } & Regressive & Adaptive & Progressive \\
\hline $\begin{array}{c}\text { Enterprise } \\
\text { development }\end{array}$ & $\begin{array}{c}\text { Orientation to state } \\
\text { subsidies, lack of } \\
\text { perspective development, } \\
\text { lack of innovation }\end{array}$ & $\begin{array}{c}\text { Simple reproduction } \\
\text { with advanced } \\
\text { elements, imitation } \\
\text { innovation }\end{array}$ & $\begin{array}{c}\text { Integrated } \\
\text { innovation } \\
\text { development }\end{array}$ \\
\hline
\end{tabular}




\begin{tabular}{|c|c|c|c|}
\hline $\begin{array}{c}\text { Ways to create } \\
\text { value added } \\
\text { The added value }\end{array}$ & Operating & Pinpoint investments & $\begin{array}{c}\text { Investment } \\
\text { innovation }\end{array}$ \\
\hline $\begin{array}{c}\text { Type of enterprises } \\
\text { low }\end{array}$ & $\begin{array}{c}\text { Uncompetitive, lost } \\
\text { market position }\end{array}$ & $\begin{array}{c}\text { Mining enterprises and } \\
\text { enterprises of primary } \\
\text { processing of natural } \\
\text { resources, state } \\
\text { corporations }\end{array}$ & $\begin{array}{c}\text { Leaders in the } \\
\text { creation and/or } \\
\text { implementation of } \\
\text { high technology }\end{array}$ \\
\hline $\begin{array}{c}\text { Sustainability and } \\
\text { enterprise stability }\end{array}$ & $\begin{array}{c}\text { Financially unsustainable } \\
\text { enterprise }\end{array}$ & $\begin{array}{c}\text { Financially sustainable } \\
\text { enterprise in the short } \\
\text { and/or long term }\end{array}$ & $\begin{array}{c}\text { Economically } \\
\text { sustainable } \\
\text { enterprise with } \\
\text { balanced } \\
\text { sustainability }\end{array}$ \\
\hline $\begin{array}{c}\text { The most relevant } \\
\text { forms of risk }\end{array}$ & $\begin{array}{c}\text { The inability to borrow } \\
\text { due to unsatisfactory } \\
\text { liquidity and financial } \\
\text { stability }\end{array}$ & $\begin{array}{c}\text { Internal resistance of } \\
\text { personnel, business } \\
\text { processes, tactical and } \\
\text { operational levels of } \\
\text { planning necessary } \\
\text { transformations }\end{array}$ & $\begin{array}{c}\text { Long-term } \\
\text { investment risks } \\
\text { due to innovation }\end{array}$ \\
\hline
\end{tabular}

The classification made it possible to conclude that each development strategy of an economic entity has specific risk forms and degrees of stability that determine the key features of the tactical and operational levels of enterprise management in the context of the need to attract investments of all types and forms. Thus, the strategy of an economic entity can be represented as the following dependence:

$$
\mathrm{St}=f\left\{\frac{\partial \mathrm{G}}{\partial t}, \frac{\partial \mathrm{R}}{\partial t}\right\},
$$

where St - enterprise strategy;

$\frac{\partial \mathrm{G}}{\partial t}$ - change in the degree of enterprise sustainability;

$\frac{\partial \mathrm{R}}{\partial t}$ - change in the risks of the enterprise activity.

On the other hand, the totality of endogenous processes in an enterprise must be considered taking into account the synergistic effect of transformations in economic systems of a higher level (industry, region, country).

Also, in order to achieve an innovative breakthrough on the national economy scale and make transition from raw material dependence to high-tech sectors of the national economy and import substitution of know-how facilities, an enterprise development strategy should be developed on the basis of introducing product, technological and managerial innovations with the attraction of external investments in the necessary volumes. At the same time, the study noted that a positive innovative effect from the activities of enterprises can also be achieved on the basis of strategies that actively use endogenous potential and aimed at modernizing a narrow section of the foreign market, and not just adapting their own economic activities to external conditions.

Based on this, the author proposes to consider the process of choosing a strategy for managing the innovation and investment activity of an industrial enterprise as a function of the parameters of its predicted stability and the total relative value of the sum of the risks of its activity in the context of the need to introduce product, technological and managerial 
innovations based on attracting external investments, taking into account exogenous factors of the external innovation market.

This dependence is presented in the following form:

$$
\mathrm{St}=\underbrace{\overbrace{\left\{\frac{\partial \mathrm{G}}{\partial t}, \frac{\partial \mathrm{R}}{\partial t}, \frac{\partial N P V}{\partial \mathrm{t}}\right\}}^{\mathrm{f}(\text { innov })}}_{\mathrm{f}(\text { exo })},
$$

where $f($ innov ) - investment attractiveness of an enterprise;

$f($ exo $)$ - a set of exogenous factors of the innovation market;

$\frac{\partial N P V}{\partial \mathrm{t}}$ - change in the net present value of an enterprise.

Based on the identified dependence, the author has generated and proposed an algorithm for determining the strategy for managing the innovation and investment activity of an industrial enterprise, which can also serve as an analytical tool for adjusting a previously defined strategy and clarifying the mission of an economic entity.

\section{Discussion}

The developed author's approach to choosing a strategy for managing innovative and investment activities of an economic entity allows the management and owners of the enterprise to determine the most acceptable innovative development strategy with a preliminary assessment of the forms and sizes of the necessary investment resources, with the possibility of adjusting the strategy at any stage of its practical implementation. A key feature of the author's algorithm is the choice of an innovative strategy based on the analysis of the parameters of the predicted sustainability of an enterprise under the given conditions of the need to introduce product, technological and managerial innovations by attracting external investment, taking into account exogenous factors of the external innovation market.

\section{Conclusion}

The proposed model methodology allows taking into account the differences in the ways of investment support of innovative transformations depending on the current stage of enterprise development.

The study identifies and characterizes the main types of strategies of economic entities in terms of their innovation and investment development. This allowed considering the process of choosing an enterprise development strategy in the form of a function of the parameters of its predicted sustainability and the cumulative relative amount of the sum of the risks of its activities in the context of the need to introduce product, technological and managerial innovations by attracting external investment, taking into account exogenous factors of the external innovation market. Based on the identified dependence, the author has developed an algorithm for determining the strategy for managing innovative and investment activities of an enterprise, the key feature of which is the choice of strategy based on a comprehensive analysis of the parameters of the predicted stability of an enterprise. At the same time, the dependence of the relative value of the necessary investment resources, which allow ensuring the sustainable development of an enterprise, on the value of the probabilistic assessment was revealed. 


\section{References}

1. K.E. Kovalenko, S.Y. Bakhvalov, A.O. Zekiy, V.V. Vikulina, S.A. Tinkov, T.V. Tkacheva, Journal of Entrepreneurship Education 22(3), 1-7 (2019)

2. S.A. Tinkov, E.V. Tinkova, FarEastCon 2018 Smart Innovation, Systems and Technologies, Springer 139 (2019)

3. N. Safronova, E. Nezhnikova, A. Kolhidov, MATEC Web of Conferences 106, 08024 (2017)

4. A. Larionov, L. Metechko, A. Davydov, D. Davydov, MATEC Web of Conferences 193, 04027 (2018)

5. L. Ustinovicius, R. Rasiulis, L. Nazarko, T. Vilutienè, M. Reizgevicius, Procedia Engineering 122, 166-171 (2015)

6. A. Aurora, S. Teixeira, A. Queirós, Research Policy 45, 1636-1648 (2016)

7. K. Kulakov, S. Belyaeva, O. Belyantseva, A. Gamisoniya, MATEC Web of Conferences conference proceedings, 01118 (2018) 